\title{
HORMONAL RECEPTOR, HUMAN EPIDERMAL GROWTH FACTOR AND ITS ASSOCIATION WITH BREAST CANCER TUMOR CHARACTERISTICS IN ALBANIA
}

\author{
Edlira Pajenga', Tefta Rexha'2, Silva Çeliku ${ }^{3}$, Ana Ugrinska ${ }^{4}$, Gazmend Bejtja ${ }^{5}$ \\ 'Department of Biology, Faculty of Natural Science, University of Elbasan, Elbasan, Albania \\ ${ }^{2}$ Department of Biology, Faculty of Natural Science, University of Tirana, Tirana, Albania \\ ${ }^{3}$ Division of Gynaecology, Mother Tereza Oncology Hospital, Tirana, Albania \\ ${ }^{4}$ Institute of Pathophysiology and Nuclear Medicine, Acad Isak S. Tadzer Faculty of Medicine, UKIM, Skopje, Republic of Macedonia \\ ${ }^{5}$ Division of Public Health, Ministry of Health, Tirana, Albania
}

\section{SUMMARY}

Aim: This retrospective study was designed to analyze expression patterns of estrogen receptor (ER), progesterone receptor (PR) and HER2/neu in Albanian patients with breast carcinoma to identify their relationships with tumor size, histological grade (HG), lymph node metastasis and relapse.

Methods: Patients with either biopsy or metastatic relapse were identified. Demographics, tumor characteristics, ER, PR, and HER2/neu status were retrospectively obtained from the medical records of patients treated with breast cancer during 2006-2011. Hormonal receptors and HER2/ neu were assessed by immunohistochemistry. Association of ER, PR and HER2/neu with clinicopathological and molecular characteristics were studied using Fisher's test. $P$ value $\leq 0.05$ was considered significant.

Results: There were 110 patients included in the study. Mean patient age was $51.08 \pm 10.75$ years. The overall immunoexpression of ER, PR and HER2/neu were found positive in $76(69 \%), 73(67 \%)$, and $16(41 \%)$ patients, respectively. ER- was associated with higher histological grade ( $24 \%$ vs. $9.2 \%$ ) and $P R+$ with tumor size (T2, 78.3 vs. 64.3$)(p=0.02$ and 0.05 , respectively). ER and PR expression were significantly decreased in HER2/neu positive cases while HER2/neu levels correlated with tumor size $(p=0.03)$ and nodal metastasis $(p=0.03)$. No association was detected between ER, PR, HER2/neu and relapse.

Conclusion: A combination of ER, PR and HER2/neu and prognostic factors could be of clinical value by defining subgroups in Albanian breast cancer patients that might benefit from more aggressive treatment.

Key words: breast cancer, ER, PR, HER2/neu, relapse

Address for correspondence: E. Pajenga, Department of Biology, Faculty of Natural Science, University of Elbasan, Lagja 11 Nentori, Rruga Rinia, Elbasan, Albania. E-mail: eda@enet.al

http://dx.doi.org/10.21101/cejph.a4085

\section{INTRODUCTION}

Estrogen receptor (ER) and progesterone receptor (PR) expressions are the most important and useful predictive factors currently available. ER and PR are intracellular steroid hormone receptors which have received a great attention since 1986 . Measurable amounts of ER and PR are found in about 50-85\% of patients with breast cancer. Steroid receptor testing for ER and PR by immunohistochemistry is the established standard of care with almost $70-80 \%$ of the tumors in breast cancer being ER and/or PR positive (1). The frequency of positivity and the level of ER and PR increase with age, reaching their highest levels in postmenopausal women (2). Men have higher ER and PR expression as compared to female breast cancer patients without any association with histological prognostic markers (3).

Factors that are known to be important in the prognosis of breast malignancies in individual patients include: size of the primary tumor, stage of the disease at diagnosis, hormonal recep- tor status, and number of lymph nodes involved with disease. A number of studies have shown the prognostic and predictive significance of ER and PR in breast cancer patients $(1,4-6)$. Generally, the frequency of receptor positivity is inversely correlated with HER2/neu $(7,8)$. Negative ER, PR have been found to be associated with higher tumour grade, larger tumour size, aggressive histopathological type, and recurrence $(9,10)$.

Overexpression of the HER2/neu oncogene is also important event in breast cancer tumorigenesis. The HER2/neu receptor is a member of the epidermal growth factor receptor family of receptor tyrosine kinases, which are considered to be important mediators of cell proliferation and differentiation (11). It is activated in $20 \%$ to $30 \%$ of cases through amplification and overexpression of the oncogene. Overexpression of HER2/neu reflects an increased proliferative activity of the tumor. HER2/neu positivity has been reported to be a negative predictor of response to hormonal therapy, adjuvant radiotherapy, and adjuvant chemotherapy (12, 13). The determination of correct HER2/neu tumor status is criti- 
cally important for guiding the therapy of patients with HER2/neu positive breast cancer treated with Trastuzumab (Herceptin) (14).

The objective of this study was to determine the biological differences that exist between steroid hormone receptor and epidermal growth factor receptor-2 and their association with histological prognostic markers in female breast carcinoma in Albania.

\section{MATERIALS AND METHODS}

The association between breast tumor characteristics and expression of ER, PR, HER2/neu, patient's age, tumor size, lymph nodes status, and tumor grade were retrospectively evaluated in primary breast cancer patients diagnosed between January 2006 and December 2007 at "Nene Tereza" Oncologic Hospital in Tirana, treated till January 2010 - December 2011. The study population included 123 patients in the age group of 26-76 years. Among them 11 patient who had benign breast diseases and 2 male patients were excluded from the study. Only 110 histologically confirmed female breast cancer patients in different stages of the disease were selected for our study. Median follow-up for all of the patients analyzed is 48.4 month (range 36.2-64.4 months). All patient characteristics are listed in Table 1.

Patients were grouped according to age $\leq 50$ years and $>50$ years. Age of the patient was taken as age rounded to the nearest figure in years at the time of biopsy/surgery of the tumor. Tumor size was classified as $<2 \mathrm{~cm}, 2-5 \mathrm{~cm}$ and $>5 \mathrm{~cm}$ and lymph nodes were grouped as $1-3,4-9$ and $>9$ based on TNM staging for breast carcinoma.

Factors that are known to be important in the prognosis of breast malignancies in individual patients include: size of the primary tumor, stage of the disease at diagnosis, histological grade hormonal, receptor status, and lymph nodes involved with the disease $(15,16)$. This retrospective of tumors was of interest because considerable information was available on the majority of the specimens including size of the primary tumor, estrogen receptor status, progesterone receptor status, age of patient, disease stage, HER2/neu, and status of the lymph nodes. Representative sections with tumor and the adjacent normal breast tissue were processed for ER, PR and HER2/neu immunohistochemical staining. For ER and PR staining, sections were taken on histogrip coated slides. Antigen retrieval was done by citrate buffer and the slides were stained with monoclonal antibodies against estrogen and progesterone receptors, 790-4324, anti-ER (SP1) and 7902223, anti-PR (1E2), (Ventana Inc).

For HER2/neu staining, after antigen retrieval, slides were marked with antibody against HER2/neu oncoprotein, PATHWAY anti-HER2/neu, 790-2991, (Ventana Inc). The slides were counterstained with Mayer hematoxylin. The intensity of HER2/neu overexpression was graded by $0,1+, 2+$, or $3+$. Overexpression of HER2/neu was defined as positive $2+, 3+$ membranous staining in the invasive carcinoma cells.

Tumor specimens were considered negative for ER and PR if staining for both receptors was negative; specimens were considered positive for ER/PR if staining for both receptors was positive. A scoring system was also used, which was based on the estimated fraction of positively stained cells. Some authors regard any evincible staining $(>0 \%)$ as a positive result, (17, 18) whereas some use $10 \%,(19)$ or at least $20 \%$ nuclei staining as positive results (20). Therefore, in the current study, we used the percentage of positive malignant cells, and the cutoff points for negative expression were less than $10 \%$ of positive nuclear staining.

\section{Statistical Analyses}

Continuous variables were described by the median with range, and qualitative variables by the size and percentage rate. We used Freeman-Halton extension of Fisher's test to compute the two-tailed probabilities in contingency tables to examine the categorical variables and to assess possible associations between clinicopathological and molecular factors. The results were considered statistically significant if the $p$ value was $\leq 0.05$. All analyses were performed with SPSS version 15 for Windows.

Table 1. Clinicopathological and molecular characteristics of the breast cancer patients

\begin{tabular}{|l|c|c|}
\hline Features & N & $\%$ \\
\hline Total cases & 110 & 100.0 \\
\hline Age & 55 & 50.0 \\
\hline$\leq 50$ years old & 55 & 50.0 \\
\hline$>50$ years old \\
\hline \multicolumn{3}{|l|}{} \\
\hline Tumor size & 16 & 14.5 \\
\hline T2 & 76 & 69.1 \\
\hline T3 & 11 & 10.0 \\
\hline T4 & 7 & 6.4 \\
\hline Todal
\end{tabular}

Nodal status

\begin{tabular}{|c|c|c|}
\hline N0 & 19 & 17.3 \\
\hline N1 & 86 & 78.2 \\
\hline N2 & 5 & 4.5 \\
\hline N3 & 0 & 0.0 \\
\hline
\end{tabular}

Histological grade

\begin{tabular}{|l|c|c|}
\hline I & 9 & 8.2 \\
\hline II & 86 & 78.2 \\
\hline III & 15 & 13.6 \\
\hline
\end{tabular}

Receptor status

\begin{tabular}{|l|l|l|}
\hline ER+ & 76 & 69.1 \\
\hline ER- & 34 & 30.9 \\
\hline PR+ & 73 & 66.4 \\
\hline PR- & 37 & 33.7 \\
\hline
\end{tabular}

HER2/neu status

\begin{tabular}{|l|l|l|}
\hline HER2+ & 16 & 14.5 \\
\hline HER2- & 23 & 20.9 \\
\hline Missing & 71 & 64.5 \\
\hline Relapse & 93 & 84.5 \\
\hline No & 17 & 15.5 \\
\hline Yes & \multicolumn{2}{|l}{} \\
\hline
\end{tabular}




\section{RESULTS}

This study is, to our knowledge, the only comprehensive evaluation of the biological and clinical characteristics of Albanian breast cancers patients that are $\mathrm{ER}+, \mathrm{PR}+$ or $\mathrm{HER} 2 / \mathrm{neu}+$ compared with those that are ER-, PR- or HER2/neu-. There were 110 breast cancer patients analyzed during the study period. The frequency of ER, PR patients with age, tumour size, number of nodes involved, histological grade, HER2/neu, and recurrent disease are summarized in Table 2. The mean patients age was 51 (28-71 years) with $\mathrm{SD}=10.74$. The overall ER expression was $69 \%$ and PR expression 67\%. ER- and PR- tumors were more frequent at age $>50$ years, while receptors positive were particularly high among women aged less than 50 years.

The majority of the patients, $76 \%$ of ER negative tumors and $78 \%$ of PR negative expression were in T2 stage. In this respect, only $1,8 \%$ of ER negative tumors were in stage T1 compared with $12,7 \%$ in ER positive group and $0,9 \%$ PR negative tumors presented with T1 stage compared with $13,8 \%$ in PR positive group. However, ER receptor did not show statistically significant association with tumor stage.

Histological grade III was more common in ER, PR negative tumors ( $24 \%$ and $24 \%$, respectively), which was higher in comparison with $\mathrm{ER}+, \mathrm{PR}+$ phenotype $(9.2 \%$ and $8 \%$, respectively). A positive association was seen between histological grade and negative steroid receptors expressions (Table 2). Amongst 110 patients with breast carcinoma, lymph node metastases were present in 63 cases (57\%) with ER expression and 60 cases (55\%) with PR expression. Tumors with lymph node metastasis showed no association with ER and PR.
Relapse rate was not affected by estrogen and progesterone receptors expression. Nevertheless, ER- and PR- tumors were more likely than ER+ and PR+ tumors to relapse (18\% and 19\% vs. $14 \%$, respectively).

Because of patient factors as well as service factors, HER2/ neu over-expression/amplification testing was not being routinely advised. As a result, only in 39 from 110 patients HER2/neu analysis was conducted. Overexpression of HER2/neu was seen in $16(41 \%)$ of our patients. Triple positivity $(\mathrm{ER}+, \mathrm{PR}+, \mathrm{HER} 2 /$ neu + ) was expressed in only $10 \%$ of the patients, compared with $31 \%$ of the patients HER2/neu positive and steroid receptors negative. Furthermore, triple negative tumors occurred in $21 \%$ of the patients in our study (Table 3 ). In the HER2/neu breast cancer patients was found a statistically significant inverse association of HER2/neu with ER/PR receptors ( $p=0.02$ ) (Table3). ER/PR negative tumors were more likely to be HER $2 /$ neu positive $(75 \%)$ than were ER/PR positive tumors. Our findings showed a significant correlation of tumor size $(\mathrm{p}=0.003)$ and nodal status $(\mathrm{p}=0.03)$ with HER2/neu overexpression. The likelihood of having metastatic disease increased in the group of patients with HER2/neu overexpressing protein (69\% vs. 35\%). Recurrent disease was noted in $6(15 \%)$ patients. No associations were found between relapse and histological grade and HER2/neu tumors.

\section{DISCUSSION}

This study focused on the evaluation of relationship between clinicopathological and molecular factors in a poor studied group of Albanian women. Although there is an agreement on the prog-

Table 2. Association of ER and PR with prognostic markers in early breast cancer $(N=110)$

\begin{tabular}{|c|c|c|c|c|c|c|}
\hline & ER+ & ER- & $p$ value & PR+ & PR- & $p$ value \\
\hline \multicolumn{7}{|l|}{ Age } \\
\hline$\leq 50$ years & 44 & 11 & \multirow{2}{*}{0.02} & 43 & 12 & \multirow{2}{*}{0.01} \\
\hline$>50$ years & 32 & 23 & & 30 & 25 & \\
\hline \multicolumn{7}{|l|}{ Tumor size } \\
\hline $\mathrm{T} 1$ & 14 & 2 & \multirow{4}{*}{0.30} & 15 & 1 & \multirow{4}{*}{0.05} \\
\hline $\mathrm{T} 2$ & 50 & 26 & & 47 & 29 & \\
\hline T3 & 8 & 3 & & 6 & 5 & \\
\hline $\mathrm{T} 4$ & 4 & 3 & & 5 & 2 & \\
\hline \multicolumn{7}{|l|}{ Nodal status } \\
\hline NO & 13 & 6 & \multirow{3}{*}{1.00} & 13 & 6 & \multirow{3}{*}{1.00} \\
\hline $\mathrm{N} 1$ & 59 & 27 & & 57 & 29 & \\
\hline N2 & 4 & 1 & & 3 & 2 & \\
\hline \multicolumn{7}{|c|}{ Histological grade } \\
\hline I & 17 & 2 & \multirow{3}{*}{0.02} & 7 & 2 & \multirow{3}{*}{0.08} \\
\hline$\|$ & 62 & 24 & & 60 & 26 & \\
\hline III & 7 & 8 & & 6 & 9 & \\
\hline \multicolumn{7}{|l|}{ Relapse } \\
\hline No & 65 & 28 & \multirow{2}{*}{0.70} & 63 & 30 & \multirow{2}{*}{0.40} \\
\hline Yes & 11 & 6 & & 10 & 7 & \\
\hline
\end{tabular}


Table 3. Summary of characteristics of HER2/neu positive vs. negative

\begin{tabular}{|c|c|c|c|}
\hline & HER2+ & HER2- & $p$ value \\
\hline \multicolumn{4}{|l|}{ Age } \\
\hline$<50$ years & 9 & 14 & \multirow{2}{*}{1.00} \\
\hline$\geq 50$ years & 7 & 9 & \\
\hline \multicolumn{4}{|l|}{ Tumor size } \\
\hline $\mathrm{T} 1$ & 1 & 10 & \multirow{2}{*}{0.03} \\
\hline T2-T3 & 14 & 13 & \\
\hline \multicolumn{4}{|l|}{ Nodal status } \\
\hline NO & 4 & 15 & \multirow{2}{*}{0.03} \\
\hline $\mathrm{N} 1-\mathrm{N} 2$ & 12 & 8 & \\
\hline \multicolumn{4}{|l|}{$H G$} \\
\hline I & 2 & 2 & \multirow{2}{*}{0.70} \\
\hline$\|-1\|$ & 14 & 21 & \\
\hline \multicolumn{4}{|c|}{ Receptor Status } \\
\hline ER+/PR+ & 4 & 15 & \multirow{2}{*}{0.02} \\
\hline ER-/PR- & 12 & 8 & \\
\hline \multicolumn{4}{|l|}{ Relapse } \\
\hline No & 15 & 18 & \multirow{2}{*}{0.30} \\
\hline Yes & 1 & 5 & \\
\hline
\end{tabular}

nostic and predictive significance of testing ER expression, the additional benefit from the assessment of PR receptor still remains controversial (5). In Albania, the significance of hormone receptors and HER2/neu expression and their potential association and prognosis are still largely unknown.

Our data showed the significant association of ER receptor expression with histological grade and PR expression with tumor size. In our study, as compared with others $(9,10,22-24)$, no correlation was found between ER or PR and lymph node status, suggesting that the hormonal receptors are not predictors of metastatic potential. Among patients with ER- and PR-tumors, recurrence was higher than in $\mathrm{ER}+, \mathrm{PR}+$ tumors but association was not significant as seen in previous studies (25).

The frequency of hormones receptor-positive breast cancer has been found to be high as in the western countries (65\% to $80 \%)$ $(26,27) . \mathrm{ER}+$ and PR+ tumors were more likely to be associated with younger age at diagnosis compared to ER- and PR- tumors. $\mathrm{ER}-, \mathrm{PR}$ - tumors displayed features of a more aggressive biological phenotype than ER+, PR+ tumors. This evaluation allowed identification of patients with high-risk features for whom new treatments are needed $(1,4-6)$.

HER2/neu levels are closely associated with adverse clinicopathological and molecular factors. In his work, Seshadri et al. (28) studied a group of 1,056 patients with breast cancer diagnosed between 1987 and 1990. After a median follow up of 39 months, he concluded that overexpression of HER2/neu correlated significantly with stages of disease, with lymph nodes and absence of ER, PR receptors. In our study, the elevated values of HER2/neu tissue status in the primary tumors were associated significantly with tumor size, nodal status and decreased hormonal receptors.

We showed that the presence of ER and PR receptors in human breast cancer cell lines resulted in a strong reduction of
HER2/neu protein overexpression. HER2/neu overexpression correlated with absence of ER expression $(3,21,28-31)$ which is in line with other studies. The exact molecular mechanism of this phenomenon remains to be elucidated, but the finding of estrogen-mediated down-regulation of HER2/neu in breast cancer cell lines implies the existence of reciprocal control at the level of gene regulation (32). In our results, 16 (41\%) of the breast cancer women had HER2/neu overexpression. In general, $70-90 \%$ of all breast cancer patients are considered to be HER $2 /$ neu negative by standard tissue tests $(12,13)$. The higher percentage of HER2/neu positive tumors might be attributed to the low number of patients undergoing HER2/neu analysis, which limited the number of subgroups HER2/neu+ and HER2/neu- cases, engendering possible insignificant differences. Considering the importance of evaluating HER2/neu expression, we strongly feel that this issue should be further investigated taking into account patients' management and alternative therapeutic strategies (33).

The overexpression of HER2/neu reflects the activity of tumor cells and the clinical course of disease towards progression or regression. HER2/neu plays an important role in cell proliferation and differentiation, and its overexpression seems to correlate with an increase in the proliferative activity of breast cancer cells (28, $34)$. We also showed that the HER $2 /$ neu status was a prognostic indicator and HER2/neu+ patients had higher metastatic potential than HER $2 / \mathrm{neu}^{-}$patients ( $75 \%$ vs. $34.7 \%$ ). Analysis of all breast cancer patients for elevated HER2/neu levels can provide valuable information for patient management in both the HER2/neu positive and HER2/neu negative groups. ER signalling pathways in breast cancer and HER2/neu overexpression are associated with resistance to hormonal therapy which would take in consideration alternative therapeutic strategies as the number of HER2/neu targeted drug choices continues to increase.

\section{CONCLUSION}

A combination of ER, PR and HER2/neu and prognostic factors could be of clinical value in defining subgroups in Albanian breast cancer patients that might benefit from more aggressive treatment.

\section{Conflict of Interests}

None declared

\section{REFERENCES}

1. Allerd DC, Carlson RW, Berry DA, Burstein HJ, Edge SB, Goldstein LJ, et al. NCCN Task Force Report: estrogen receptor and progesterone receptor testing in breast cancer by immunohistochemistry. J Natl Compr Canc Netw. 2009 Sep; 7 Suppl 6:S1-S21; quiz S22-3.

2. Masood S. Assessment of prognostic factors in breast fine-needle aspirates. Am J Clin Pathol. 2000 May;113(5 Suppl 1):S84-96.

3. Lal P, Tan LK, Chen B. Correlation of HER-2 status with estrogen and progesterone receptors and histologic features in 3,655 invasive breast carcinomas. Am J Clin Pathol. 2005 Apr;123(4):541-6.

4. Cianfrocca M, Gradishar W. New molecular classifications of breast cancer. CA Cancer J Clin. 2009 Sep-Oct;59(5):303-13.

5. Rakha EA, Ellis IO. An overview of assessment of prognostic and predictive factors in breast cancer needle core biopsy specimens. J Clin Pathol. 2007 Dec;60(12):1300-6.

6. Thompson AM, Jordan LB, Quinlan P, Anderson E, Skene A, Dewar JA, et al; Breast Recurrence in Tissues Study Group. Prospective comparison of switches in biomarker status between primary and recurrent breast 
cancer: the Breast Recurrence In Tissues Study (BRITS). Breast Cancer Res. 2010;12(6):R92.

7. Kariya S, Ogawa Y, Nishioka A, Moriki T, Ohnishi T, Ito S, et al. Relationship between hormonal receptors, HER-2, p53 protein, bcl-2, and MIB-1 status and the antitumor effects of neoadjuvant anthracyclinebased chemotherapy in invasive breast cancer patients. Radiat Med. 2005 May;23(3):189-94.

8. Kaptain S, Tan LK, Chen B. Her-2/neu and breast cancer. Diagn Mol Pathol. 2001 Sep;10(3):139-52.

9. Jalava P, Kuopio T, Huovinen R, Laine J, Collan Y. Immunohistochemical staining of estrogen and progesterone receptors: aspects for evaluating positivity and defining the cutpoints. Anticancer Res. 2005 May-Jun;25(3c):2535-42.

10. Pinto AE, Areia F, Pereira T, Cardoso P, Aparício M, Silva GL, et al. Clinical relevance of the reappraisal of negative hormone receptor expression in breast cancer. Springerplus. 2013 Aug 9;2:375.

11. Roskoski R Jr. The ErbB/HER receptor protein-tyrosine kinases and cancer. Biochem Biophys Res Commun. 2004 Jun 18;319(1):1-11.

12. Ivkovic-Kapicl T, Knezevic-Usaj S, Djilas-Ivanovic D, Panjkovic M Correlation of HER-2/neu protein overexpression with other prognostic and predictive factors in invasive ductal breast cancer. In Vivo. 2007 Jul-Aug;21(4):673-8. Erratum in: In Vivo. 2007 Sep-Oct;21(5):955. In Vivo. 2007 Nov-Dec;21(6):1172.

13. Selvarajan S, Wong KY, Khoo KS, Bay BH, Tan PH. Over-expression of c-erbB-2 correlates with nuclear morphometry and prognosis in breast carcinoma in Asian women. Pathology. 2006 Dec;38(6):528-33.

14. Slamon DJ, Leyland-Jones B, Shak S, Fuchs H, Paton V, Bajamonde A, et al. Use of chemotherapy plus a monoclonal antibody against HER2 for metastatic breast cancer that over $e x p r e s s e s$ HER2. N Engl J Med. 2001 Mar 15;344(11):783-92

15. Hayes DF, Isaacs C, Stearns V. Prognostic factors in breast cancer: current and new predictors of metastasis. J Mammary Gland Biol Neoplasia. 2001 Oct;6(4):375-92.

16. Goussard J, Génot JY. What can be now expected of the determination of estrogen and progesterone receptors in the treatment of breast cancers. Bull Cancer. 1994 Jan;81(1):22-8. (In French.)

17. Putti TC, El-Rehim DM, Rakha EA, Paish CE, Lee AH, Pinder SE, et al Estrogen receptor-negative breast carcinomas: a review of morphology and immunophenotypical analysis. Mod Pathol. 2005 Jan;18(1):26-35.

18. Layfield LJ, Gupta D, Mooney EE. Assessment of tissue estrogen and progesterone receptor levels: A survey of current practice, techniques, and quantitation methods. Breast J. 2000 May;6(3):189-196.

19. Regitnig P, Reiner A, Dinges HP, Höfler G, Müller-Holzner E, Lax SF, et al. Quality assurance for detection of estrogen and progesterone receptors by immunohistochemistry in Austrian pathology laboratories. Virchows Arch. 2002 Oct;441(4):328-34.

20. Abd El-Rehim DM, Ball G, Pinder SE, Rakha E, Paish C, Robertson JF, et al. High-throughput protein expression analysis using tissue microarray technology of a large well-characterised series identifies biologically distinct classes of breast cancer confirming recent cDNA expression analyses. Int J Cancer. 2005 Sep 1;116(3):340-50,

21. Huang HJ, Neven P, Drijkoningen M, Paridaens R, Wildiers H, Van Limbergen E, et al. Association between tumor characteristics and HER-2 neu by immunohistochemistry in 1362 women with primary operable breast cancer. J Clin Pathol. 2005 Jun;58(6):611-6.
22. Martinez SR, Young SE, Giuliano AE, Bilchik AJ. The utility of estrogen receptor, progesterone receptor and Her 2/ neu status to predict survival in patients undergoing hepatic resection for breast cancer metastases. Am J Surg. 2006 Feb;191(2):281-3

23. Ambroise M, Ghosh M, Mallikarjuna VS, Kurian A. Immunohistochemical profile of breast cancer patients at a tertiary care hospital in South India. Asian Pac J Cancer Prev. 2011;12(3):625-9.

24. Bartlett JM, Ellis IO, Dowsett M, Mallon EA, Cameron DA, Johnston $\mathrm{S}$, et al. Human epidermal growth factor receptor 2 status correlates with lymph node involvement in patients with estrogen receptor (ER) negative, but with grade in those with ER-positive early-stage breast cancer suitable for cytotoxic chemotherapy. J Clin Oncol. 2007 Oct 1;25(28):4423-30.

25. Arpino G, Weiss H, Lee AV, Schiff R, De Placido S, Osborne CK, et al. Estrogen receptor-positive, progesterone receptor-negative breast cancer: association with growth factor receptor expression and tamoxifen resistance. J Natl Cancer Inst. 2005 Sep 7;97(17):1254-61.

26. Stierer M, Rosen H, Weber R, Hanak H, Spona J, Tüchler H. Immunohistochemical and biochemical measurement of estrogen and progesterone receptors in primary breast cancer correlation of histopathology and prognostic factors. Ann Surg. 1993 Jul;218(1):13-21.

27. Li CI, Daling JR, Malone KE. Incidence of invasive breast cancer by hormone receptor status from 1992 to 1998. J Clin Oncol. 2003 Jan $1 ; 21(1): 28-34$

28. Seshadri R, Firgaira FA, Horsfall DJ, McCaul K, Setlur V, Kitchen P. Clinical significance of HER-2/neu oncogene amplification in primary breast cancer. The South Australian Breast Cancer Study Group. J Clin Oncol. 1993 Oct;11(10):1936-42.

29. Rosai J, Ackerman LV, editors. Ackerman's surgical pathology. 9th ed. St. Louis: CV Mosby; 2004.

30. Yau TK, Sze H, Soong IS, Hioe F, Khoo US, Lee AW. HER2 overexpression of breast cancers in Hong Kong: prevalence and concordance between immunohistochemistry and in-situ hybridisation assays. Hong Kong Med J. 2008 Apr;14(2):130-5.

31. Ariga R, Zarif A, Korasick J, Reddy V, Siziopikou K, Gattuso P. Correlation of her-2/neu gene amplification with other prognostic and predictive factors in female breast carcinoma. Breast J. 2005 Jul-Aug;11(4):278-80.

32. Grunt TW, Saceda M, Martin MB, Lupu R, Dittrich E, Krupitza G, et al Bidirectional interactions between the estrogen receptor and the cerbB-2 signaling pathways: heregulin inhibits estrogenic effects in breast cancer cells. Int J Cancer. 1995 Nov 15;63(4):560-7.

33. Mostratos Z, Domeyer PR, Michalis D. Cancer mortality in Greece: where are we heading? A 20-year comparative study in four Greek counties. Cent Eur J Public Health. 2006 Sep;14(3):113-6.

34. Molina R, Ciocca DR, Tandon AK, Allred DC, Clark GM, Chamness $\mathrm{GC}$, et al. Expression of HER-2/neu oncoprotein in human breast cancer: a comparison of immunohistochemical and western blot techniques. Anticancer Res. 1992 Nov-Dec;12(6B):1965-71.

Received September 1, 2014 Accepted in revised form March 7, 2016 